\title{
EFFECT OF EXCHANGE RATES AND GASOLINE PRICE ON EXPORT PRICE OF VIETNAMESE COFFEE
}

\author{
To Thi Kim Hong \\ Ho Chi Minh City Open University \\ Email: hong.ttk@ou.edu.vn
}

(Received: 03/11/2015; Revised: 05/12/2015; Accepted: 07/12/2015)

\begin{abstract}
Price fluctuation is not only an important issue to economic research but also to corporate managers, especially in agri-business industry. This research applied time series data analysis with linear models to identify and measure the impact of some factors such as exchange rate and gasoline price on the price of Vietnam's coffee exports in the period 2008-2014. With a cointegration between Vietnamese prices and world prices of coffee, the pairwise Granger test indicates the dependence of Vietnam coffee prices on world prices, but not vice-versa or Vietnam price could not affected world prices. The regression results in this study also estimate that exchange rates and gasoline price would affect export price of Vietnamese coffee. The regression models also suggest that coffee producers improve their knowledge on price signals from export markets. With better communication skills in markets sthrough the Internet, coffee producers and exporters would forecast the changes in export price to help them in production planning and empower them in trading negotiation with foreign trading companies.
\end{abstract}

Keywords: coffee, exchange rate, export, price.

\section{Introduction}

People have been drinking coffee for thousands years. Coffee is not only the second most popular drink after water, but also the most important commodity in international trade (ICO, 2003) as it contributed greatly to the total value of global transactions. Globally, the highest coffee consuming country is the US, followed by Europe and Brazil. Meanwhile, Brazil, Columbia and Vietnam are key coffee exporters to the world market. Besides that, Vietnam is one of the countries that export a lot of agricultural products to developed and developing countries. Export value brings a significant amount of foreign currency for the country, and the agricultural export value of
Vietnam has reached more than 30 billion dollars in 2014 (GSO, 2015). However, this value is affected by fluctuating market prices and the price volatility of agricultural products that is more related to most non-agricultural products and services. Price also plays an important role in the economic theories. Which guide the production and consumption. In addition export prices of agricultural products are more affected by external factors such as exchange rates and gasoline price (Tomex and Robinson, 2003). This study uses time series data to build regression models to examine the effect of exchange rate and gasoline price on the export price of Vietnamese coffee. The results provide valuable information to the stakeholders 
in risk management and investment; also for state managers in policy making.

\section{Background and conceptual framework}

There are many studies on the impact of foreign exchange rates on export prices. Zarenejad (2012) observed Iran's rice exports through supply and demand, and he concluded that the government must manage fluctuations, if the exchange rate is floating (i.e. the rate rises), export prices reduce but the quantity of exports increases.

Wang and colleagues (2012) focused on analyzing the factors affecting the price volatility of agricultural products based on the exchange rate. Through structure and pricing model using the functional reactive impulse to forecast the outcome and impact of these price changes, they found that a few factors change. This study also provides recommendations to prevent the risk of price fluctuations, and it suggests that governments should consider using macroeconomic policies and market policies.

Nguyen Minh Duc (2013) worked on the spread of commodity prices through the value chain of Vietnamese clams, and commented on the relationship between the exchange rate and price export of goods clams. It was found that if the exchange rates rise, the export price will decrease. However this result is not consistent with the research of Hoque and Razzaque (2004) as export prices similarly react with the volatility of exchange rates.

Market prices kept demand and supply quantity balance at the time of product purchase, and manufacturers need to know when they require increase or decrease production volume of goods supplied to the market. The relationship between demand and price is closely linked and volatility in market prices will affect the equilibrium price in other markets (Engle and Quagrainie, 2009). Important factors here are the prices of related goods, particularly when analyzing the effects of substitute commodity price (interchangeable commodities while satisfying needs, satisfaction levels vary) to an export price. A wide economic literature has studied the relationship between prices, either spatial or vertical. Concerning the former, a recent critical review is given by Fackler and Goodwin and Holt (2001). According to Deaton (1988), the prices of goods and commodities are affected by general agricultural prices. Substitute goods may be tea and cocoa. Tea is a popular beverage in the world and it can substitute coffee because caffeine has natural antioxidants (in the study of Durevall 2007 tea may substitute coffee in Sweden). Cocoa is often used as a substitute for coffee in many European countries. Maurice and Davis (2011), also stated that there is a positive relationship.

As input factors would affect price exports strongly, oil price in this study is used to represent input prices as in the study of Kinnucan et al (1988) which mentioned the relationship between oil prices, exchange rate and catfish prices. Ghoshray (2008) concluded that export prices in the leading nations in the world are related to each other. Microeconomic theories also mention various factors that changed the structure of demand, which also highlighted the relationship between commodity prices, incomes and demand.

Price model including macroeconomic factors and microeconomic factors such as exchange rate, world coffee prices, prices of oil, tea and cocoa prices on the world is built as following:

$$
\mathrm{P}=\mathrm{f}(\text { Exchangerate,Pworld,Poil,Ptea,Pcocoa) }
$$

\section{Data and method}

Time series data in the study is a secondary data, collected from UN Comtrade; GSO; Centre for Trade Promotion and Investment - Vietnamese Ministry of Agriculture and Rural Development; World Bank; FAO - agricultural organizations, IMF - International Monetary Fund. This research applied time series data analysis with linear 
models to identify and From the general model in previous, the empirical was developed to measure the impact of these factors on the price of Vietnam's coffee exports in the period 2008-2014 (Table 1).
The software used for analyzing and processing data is Eview7.0.

$$
P_{i}=\hat{\beta}_{0}+\hat{\beta}_{1} X_{1 i}+\hat{\beta}_{2} X_{2 i}+\hat{\beta}_{3} X_{3 i}+\hat{\beta}_{4} X_{4 i}+\hat{\beta}_{5} X_{5 i}+\sum_{j=1}^{3} Q_{j}+e_{i}
$$

Table 1. Variables in the model regression of Vietnamese coffee

\begin{tabular}{|l|l|l|l|}
\hline Variable name & Abbreviation & Symbol & Expected sign \\
\hline $\begin{array}{l}\text { Vietnamese coffee prices on } \\
\text { export }\end{array}$ & PVNCAFELB & Y & \\
\hline World coffee prices & WPCAFELB & X1 & + \\
\hline Exchange rate & EX & X2 & + \\
\hline World gasoline price & POIL & X3 & + \\
\hline World tea price & PTEA & X4 & - \\
\hline World cocoa price & PCACAO & X5 & - \\
\hline
\end{tabular}

\section{Results and Discussion}

\subsection{Consumption and exports of coffee}

According to the UN-Com trade, the powerful countries for exporting coffee in the world include Brazil, Vietnam, Indonesia, Colombia, India, Mexico, Ethiopia, Guatemala. In 2012, Brazil exported 1.5 million tons of coffee to the world with export value reaching US $\$ 5.74$ billion which is 5 times higher than the volume of Indonesian exports. According to the World Coffee Association (ICO), Brazil is the largest coffee producer in the world (with the share of $36 \%$ of total World), the second largest is Vietnam (proportion 14\%), the third is Columbia(7\%). The world consumes two kinds of coffee: Robusta and Arabica. Robusta coffee is grown in the West and Central Africa, Southeast Asia, appropriate hot and humid tropical climate. Arabica coffee which is grown in Latin America, East Africa, Arabica is suitable to cultivate at high climates, cold and rainy. Arabica price is higher than the price of Robusta.

According to the International Coffee Organization (ICO), in 2008, global consumption in 2008 reached 125 million 60- $\mathrm{kg}$ bags, up $2 \%$ compared to 122.7 million bags in 2007. Three leading coffee consuming countries are the United States, Brazil and Germany. These countries have total consumption of about $37 \%$ of the world's coffee. The growth of coffee consumption in traditional markets (the US, Germany) is slower than that in emerging markets such as Brazil, China, Vietnam, Indonesia and the Philippines.

\subsection{Fluctuation of coffee price in the} world and of the Vietnamese exported coffee

Considering the period of economic crisis starting from 2008 to now, the price of coffee dropped an alarming slump in 2009 and 2010, then gradually recovered, but at the end of 2013, the price also declines on the world market and the Vietnamese export coffee. The export value of coffee-producing countries has dropped from 10-12 billion dollars in early 1990 to 5-6 billion dollars in 2002 (FAO, 2009).

According to the data compiled from UnComtrade, the trend of prices declines from 2009 to 2010 and flourish in the next two years (graph 2.2). The Vietnamese coffee price fells to the lowest point in the year 2009 
and 2012. Prices were highest in 2011. In May Vietnam's coffee reached 2.4USD/kg.

Currently the Vietnamese price is rising slightly (98.78 cents /lb) while world prices reach 108.35 cents/lb).

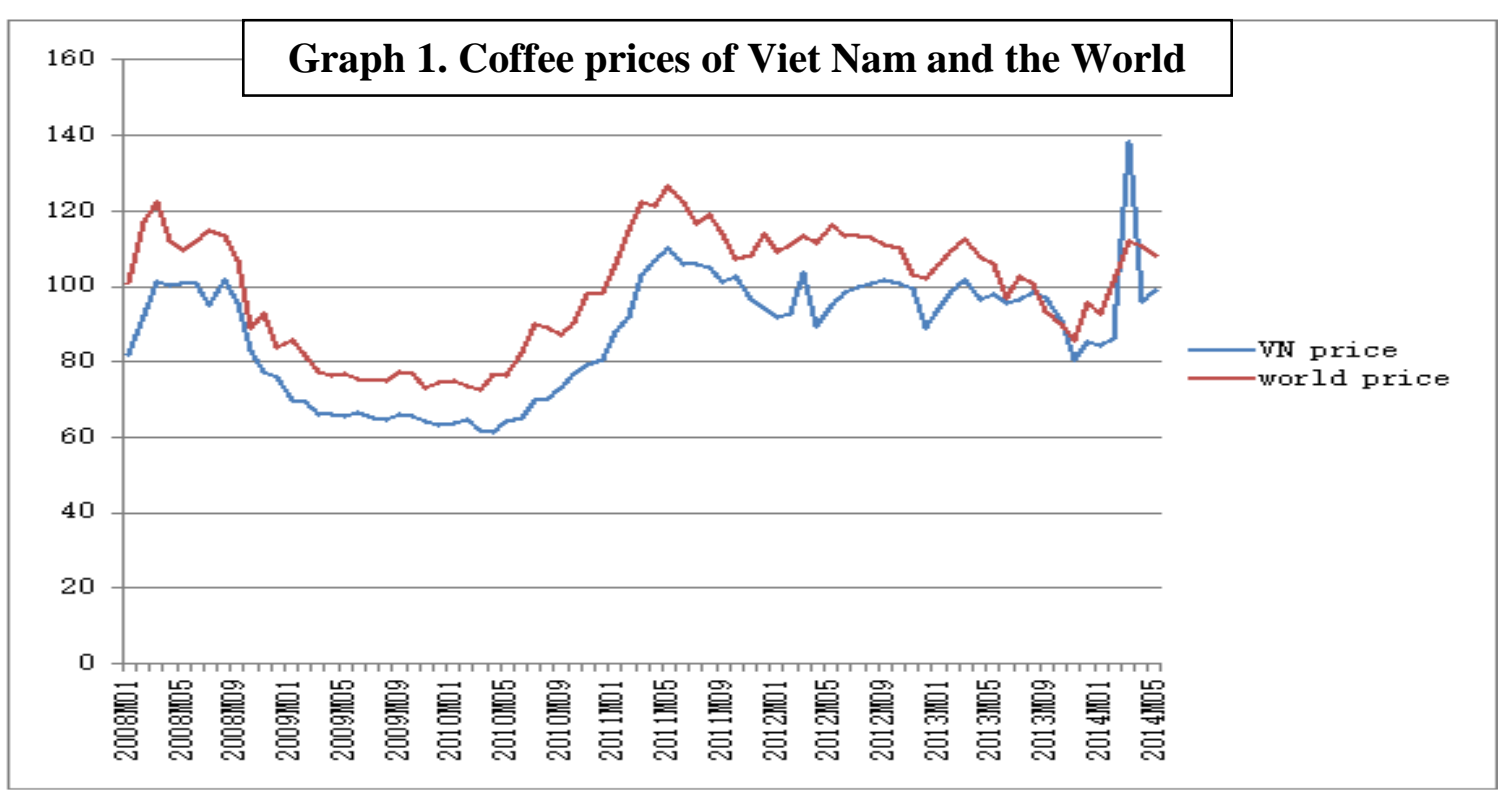

Source: FAO.

\subsection{Results of regression model}

A statistical analysis method, cointegration, was applied to analyze both the macro and micro areas as the study models the relationship between economic growth and inflation (Phung et al 2014). Especially, in the study of the cod in Norway, Asche et al (2002) suggest that prices in the different period (or different market) in value chain tend to change in a certain ratio. Giap (2010) and Germany (2010) also use this tool to test statistically the relation between the market (pond) catfish price and processed catfish in the United States.

Many studies used linear regression method for time series data, and the results are not reliable and valid because regression model has heteroskedasticity problem (Granger and Newbold, 1974). Other studies such as Von Cramon-Taubadel Loy (1999) has corrected error based on co-integration conceptual which was developed by Engle and Granger (1987) and Johansen (1988). With co-integration tests, this study predicts co-integration between Vietnamese prices and world prices of coffee in the period of economic crisis.

Augmented Dickey-Fuller Unit Root Tests are used to test unit-root for the series data on Vietnamese price and world price. Considering each data series has advanced to the level of balance and stability.

Table 2. Unit root test for Vietnam coffee prices and world price

t-Statistic Prob.

Augmented Dickey-Fuller test

statistic

$\begin{array}{lrr}\text { Exported Vietnamese price } & -1.334 & 0.6096 \\ \text { World price } & -1.399 & 0.5785\end{array}$


These results show that Vietnamese coffee prices and world prices approaching stationary in the period 01/2008 - 04/2014.

From 2008 to now (June 4/2014), this study divides integrated price fluctuations between the export price and the World price in two stages:

Stage I (from 2008-2012), Vietnam and world prices have the same tendency to each other, or they are integrated, if the price of Vietnamese coffee increases, the world price increases (Graph 2).

Stage II (from the beginning of 2013 to now), the price movements of Vietnam and the world are not in the same trend. In other words, the world and Vietnamese prices are not heterogeneous integration.

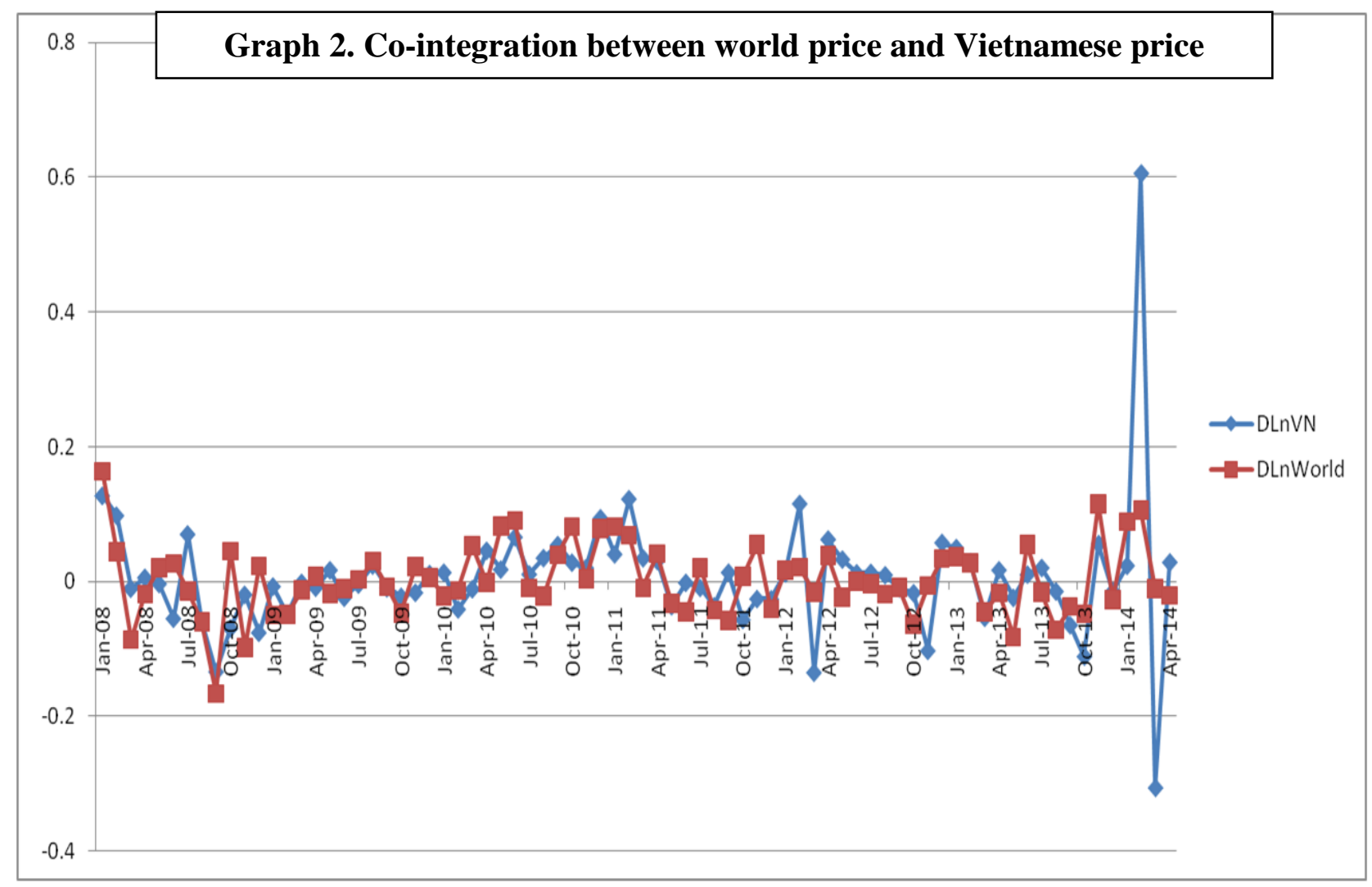

The pairwise Granger causal testing indicates world prices, but not vice-versa or Vietnamese the dependence of Vietnam coffee prices on pricecould not affect the world price (Table 3 ).

Table 3. Inspection of dependence between the Vietnamese export and World prices

\begin{tabular}{lccc}
\hline Null Hypothesis & Obs & F-statistic & Prob. \\
\hline \hline WP does not Granger Cause VNP & 75 & 15.056 & 0.000 \\
VNP does not Granger Cause WP & & 0.342 & 0.711 \\
\hline \hline
\end{tabular}

Description of the price movements on related commodities 


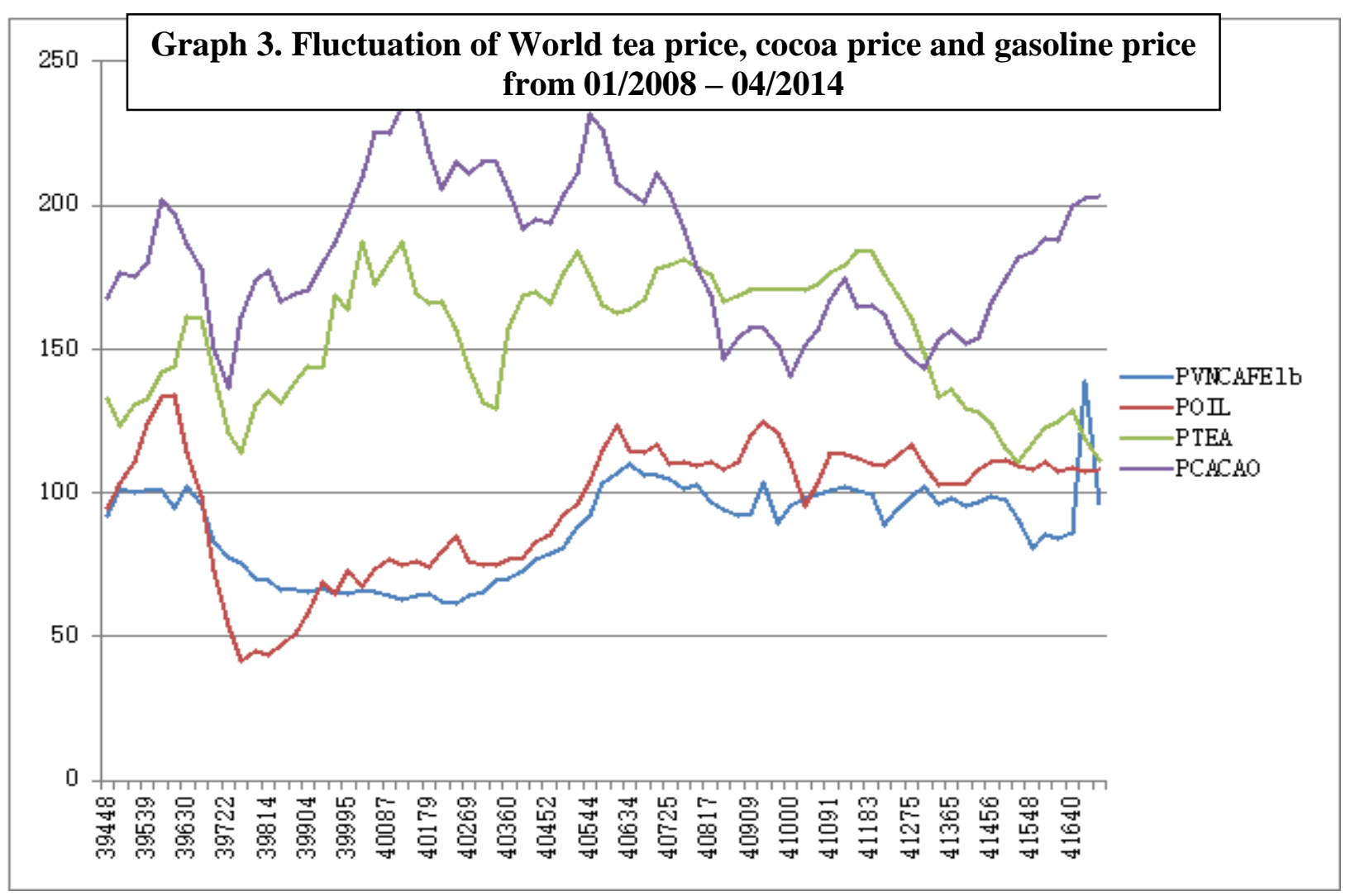

Source: IMF and Vietnamese Ministry of Agriculture and Rural Development.

Overall, four factors (gasoline price, export price of Vietnamese and world coffee, tea and cocoa prices) tended to move alike. If a commodity price increases, we will see commodity prices remaining similar developments. But in 2013, world tea and cocoa prices tended to go in opposite gap as tea prices dropped heavily, while cocoa was above the world market price.

Considering the period from 2009 onwards, the price of oil and that of
Vietnamese coffee have a strong correlation. While tea and cocoa decline sharply. Cocoa prices are highest at 234.08 and lowest at $8 / 2008$ (136.41 cents $/ \mathrm{kg})$. While the highest price of tea in $8 / 2009$ is 187.2 and the lowest price in January $9 / 2013$ is 110.86 .

Pricing model was estimated using OLS method. Correlation matrix shows that there is no strict multicollinearity between independent variables.

\begin{tabular}{|l|r|r|r|r|r|r|}
\hline & $\begin{array}{c}\text { Price of } \\
\text { Vietnam coffee }\end{array}$ & $\begin{array}{c}\text { Price of world } \\
\text { coffee }\end{array}$ & Exchange rate & Oil price & Tea price & Cacao Price \\
\hline $\begin{array}{l}\text { Price of } \\
\text { Vietnam coffee }\end{array}$ & 1 & & & & & \\
\hline $\begin{array}{l}\text { Price of world } \\
\text { coffee }\end{array}$ & 0.929 & 1 & & & & \\
\hline Exchange rate & 0.426 & 0.357 & 1 & & & \\
\hline Price of oil & 0.777 & 0.762 & 0.514 & 1 & & \\
\hline Price of tea & -0.010 & 0.111 & 0.171 & 0.179 & 1 & \\
\hline Price of cacao & -0.340 & -0.306 & -0.170 & -0.083 & 0.174 & \\
\hline
\end{tabular}


The regression result is exhibited in the following table:

\begin{tabular}{|l|l|l|l|}
\hline variable & coefficient & t-ratio & p-value \\
\hline constant & 0.575 & 0.758 & 0.45 \\
\hline Exchange rate & 0.171 & 1.847 & 0.069 \\
\hline Price of oil & 0.101 & 2.257 & 0.027 \\
\hline World price & 0.9 & 12.454 & 0.000 \\
\hline Price of cocoa & -0.07 & -1.241 & 0.219 \\
\hline Price of tea & -0.185 & -3.727 & 0.000 \\
\hline Q1 & -0.003 & -0.171 & 0.865 \\
\hline Q2 & -0.0009 & -0.046 & 0.964 \\
\hline $\mathrm{Q} 3$ & $0.044 \quad 2.139$ & 0.036 \\
\hline $\mathrm{n}=75 ; \mathrm{R}^{2}=0.909 ; \bar{R}^{2}=0.898 ; \quad$ D.W $=1.815$ & \\
\hline
\end{tabular}

The model has a high coefficient of determination with values of $\mathrm{R}$ squares is 0,909 and of Adjusted $\mathrm{R}$ squares is 0.898 . Almost coefficients have statistically significant except for coefficient corresponding cocoa price at $95 \%$ confidence level. This means the price of cocoa does not affect the export price of coffee. However, based on results of test of redundancy variable, this is not the redundancy in the model.

Regression coefficients of the variables have consistent signs which are suitable to theories. As the world market price increases, the Vietnamese coffee prices also rise. Gasoline prices and exchange rates impact the export price of Vietnam coffee.

Regression coefficients corresponding to the world price of tea, cocoa prices have negative signs. If the price of these goods rise, the price of Vietnamese coffee exports increased, which suggests that two items, tea and cocoa, may be supplementary to coffee. The result also suggests that exchange rate and gasoline price may raise export price of Vietnamese coffee, similar to studies of Kinnucan and Miao (1999).

\section{Conclusion and implication}

Using time series data, results show that exchange rates and gasoline price would raise export price of Vietnamese coffee. At 99\% confidence level, the world coffee and the Vietnamese price co-integrated each other, but Granger test confirms the Vietnamese price is affected by the world price while the Vietnamese price cannot give significant effect on the world price. Tea is considered as complementary for Vietnamese export coffee in the world market. The results from this study also confirm the effect of exchange rates and gasoline price on export price of Vietnamese coffee.

The findings from this study supplement recent market research in the Vietnamese agricultural sector and create potential empirical base for such kind of research on other agricultural products in future. Price fluctuation is not only important to economists but also to corporate managers, especially in agri-business industry. The regression results are also expected to equip coffee producers with knowledge on price signals from export markets. With better communication skills in market through the Internet, coffee producers and exporters would forecast the changes in export price to help them in production planning and empower them in trading negotiation with foreign trading companies. 


\section{REFERENCES}

Nguyen Minh Duc, (2014). Price Transmission in the Value Chain of Hard Clam (Meratrix lyrata) in Vietnam. Journal of Economic Development. University of Economics, Hochiminh City.

Tomex, W. G. and Robinson, K. L. (2003). Agricultural Product prices. Cornell University Press.

Zarenejad, M. (2012). Investigating the Elasticity of supply and demand for rice export in Iran. Research journal of recent sciences, Vol. 1 (10), page 12-18.

Wang, Y., Yang, J. and Sun, D. (2012). Study on the price of agricultural products and tendency analysis under the floating exchange rate system. Technology for education and learning, AISC 136, pp. 451-458.

Hoque, M. M. M. and Razzaque, A. (2004). Exchange rate pass-through in Bangladesh's export prices: an empirical investigation. The Bangladesh Development Studies.

Engle, C. and Quagrainie, K. (2009), Aquaculture Marketing Handbook. Wiley-Blackwell Publishing Inc. 288pp.

Deaton, A. (1988). Quality, Quantity, and Spatial Variation of Price. The American Economic Review, Vol. 78, No. 3 (Jun., 1988), pp. 418-430.

Maurice, E. N. and Davis, J. (2012). Unravelling the underlying causes of price volatility in world coffee and cocoa commodity markets. MPRA paper.

Kinnucan H.W. and Miao. Y., (1999). Media-specific Returns to Generic Advertising: The Case of Catfish. Agribusiness 15(1):81-99.

Ghoshray, A. (2008). Asymmetric adjustment of rice export prices: The case of Thailand and Vietnam. International Journal of Applied Economics, 2008, 5(2), 80-91.

Chulaphan, W., Chen, S-E., Jatuporn, C. and Huang, W-C. (2013). Different causal relationships of export rice prices in the international rice market. American-Eurasian Journal of Agriculture and Environmental Science, 13 (2): 185-190.

Asche, F., Hartmann, J., Fofana, A., Jaffry, S. \& Menezes, R. (2002). Vertical Relationships in the Value Chain: An Analysis Based on Price Information for Cod and Salmon in Europe. Working Paper, SNF Project Report No. 5310, Centre for Fisheries Economics, Institute for Research in Economics and Business Administration, Bergen, Norway.

Giap, N.V. (2010). Supply Response, Price Transmission, and Risk in the U.S. Catfish Industry. PhD Dissertation. Auburn University.

Goodwin, B.K. and Holt, M.T. (1999). Price Transmission and Asymmetric Adjustment in the U.S. Beef Sector, American Journal of Agricultural Economics, 81(3): 630-637.

Granger, C. and Newbold, P., (1974). Spurious Regression in Econometrics, Journal of Econometrics, 2: 111-120.

Engle R.F., Granger C.W.J. (1987). Co-integration and Error Correction: Representation, Estimation and Testing. Econometrica 55(2): 251-276. 